\title{
The Policy of the Department of Education Bogor Regency in Improving the Quality of PAUD Education
}

\author{
Yusi Srihartini $^{1}$, Iim Wasliman ${ }^{2}$, Yosal Iriantara ${ }^{3}$, R Supyan Sauri ${ }^{4}$ \\ ${ }^{1}$ Student of the Doctoral Graduate of the University of Islam Nusantara Bandung \\ ${ }^{2,3,4}$ Lecturer of Doctoral Graduate of the University of Islam Nusantara Bandung
}

Corresponding Author: Yusi Srihartini

\begin{abstract}
The level of education of PAUD teachers in Bogor Regency is still a lot of only junior high school or high school graduates, not meeting the National Education Standards, PAUD learning is still focused on learning to read and write arithmetic (calistung), assistance to institutions provided by the local government still does not meet the needs of the number of institutions existing PAUD. This study aims to determine the policy of the Bogor Regency Education Office in Improving the Quality of PAUD Education. This research approach with qualitative methods and data collection through observation, interviews, and documentation studies. The policy of the Bogor Regency Education Office in improving the quality of PAUD has been carried out to the maximum in the competence of its teachers by providing education and training as well as providing incentive assistance to honorary teachers although it is carried out in stages. The implementation of PAUD policies always synergizes and partners with organizations/ institutions whose members are managers and educators. Obstacles in implementing policies in Bogor Regency are still constrained in human resources, namely the number of inspectors as PAUD supervisors is not balanced with existing PAUD institutions. The results of policy implementation in improving quality with the spread of Holistic Integrative PAUD in Bogor Regency.
\end{abstract}

Keywords: Policy, Quality, PAUD Education

\section{INTRODUCTION}

Education is a field that is very important and preferred in the construction. Everyone has the right to get an education even being an obligation, especially basic education. As a consequence, the government obliged to finance the budget priority, in addition to financing the government doing programs or activities that are associated with an increase in education better quality and the amount. So, whatever the form will be done by the government to increase the participation of learners in accordance with the regulations that have been set. With the commitment of the government is expected that the community will get a chance to learn.

Education policy has an important role in determining the direction and path of the educational process, the steps taken in the decision-making to determine the policy will have no effect on the quality of the quality of education, to reduce the negative impact of the policy required the effectiveness and efficiency in the process of education policy with understand in depth the nature of education policy itself.

Public policy is a pattern of dependence of the complex of collective choices are interdependent, including decisions not to act, which is made by the agency, or government office. (William $\mathrm{N}$ Dunn, 2003) in system theory proposed Dunn in the making of public policy involves three elements, namely: Policy 
Actors, Public Policy, and environmental policy that are all inter-connected and related.

Education policy is a public policy, Education is the property of the public, and every citizen gets an equal opportunity to obtain access to a decent education. Then from that education policy is the programs planned by the government in order to overcome the problems that arise in the field of education in order to meet the obligations of the government in providing education for every citizen of the country.

In the context of education, the definition of quality includes input, process and output of education. Input education is something that should be available as needed for the sake of the continuity of a process. While the process of education is change something into something else. The Output of education is a school performance, i.e. the school's achievements resulting from the process and behavior in school. According to Deming (1982) Quality is conformance with the needs of the market or consumers, the Company is quality is the company that dominates the market because its results are in accordance with the needs of consumers, so that lead to satisfaction for consumers. If consumers feel satisfied, then they will be faithful in buying the company's products in the form of goods and services. In quality improvement there are two aspects that must be considered, namely the aspect of the quality of the results and aspects of the process of achieving results. Quality improvement related to the target to be achieved, the process to achieve and the factors associated.

The problems of the level of education of PAUD teachers in the District of Bogor there are still many who are graduates of junior high school or high school, not to meet the Standards of National Education, learning PAUD education is still focused on learning to read and write count, aid to the institution that awarded the local government still do not meet the needs of the number of institutions of PAUD education there.

\section{MATERIAL AND METHODS}

This research is a qualitative research, qualitative Research is designed to provide the real experience and capture the meaning as the field research and direct interaction between the researcher and the researched. Qualitative research aims to obtain a picture of the whole of a thing according to the view under study. The method used in this research is descriptive analytical method. Descriptive analytical method is a research method that emphasizes the effort to obtain information about the status or symptoms at the time of the study, provides an overview of the phenomenon-phenomena, also further clarifies the relationship, as well as draw the meaning of a problem that is desirable. Descriptive research is a form of research that the most fundamental and is intended to describe or depict the phenomenonphenomena that exist, the better the phenomenon that is natural or human engineering. Data collection techniques used in this research is observation/observation participate, interview, and documentation.

\section{RESULTS AND DISCUSSION}

\section{The Policy Of The Department Of Education Bogor Regency}

In the process of making and the implementation of policy through several stages, including the politicization of an issue that is called with the preparation of the policy agenda, formulation/ formulation of policy, and the legalization program, the implementation of the program/ policy implementation and monitoring and evaluation of the implementation of the program. (William N. Dunn, 2003) In the policy agenda contains therein the policy issues such as employment education PAUD education or group play at the required meet the following qualifications: candidate must possess at least Diploma/equivalent, physically and 
mentally healthy, get training, early childhood education, have the ability to manage activities/learning process of early childhood education, understanding and loving children, understanding the stages of child development, understanding the principles of early childhood education, and in the lift legally by the Manager of Group Play.

Some of the policy agenda that contains the problems faced by PAUD education based on the analysis of the facts that occurred, in line with the theory of the policy of William N. Dunn (2000) confirms the policy Analysis is a social research applied systematically compiled in order to determine the substance of the policy in order to know the clear information about the issues that are answered by the policy and the problems that may arise as a result of the application of the policy. Scope and methods of policy analysis are generally descriptive and factual about the causes and consequences of a policy.

Education Authorities Bogor Regency has a duty to help the Regent in carrying out the affairs of government in the field of education and the duty of assistance, it was stated in the Regulations of the Regent of Bogor No. 45 of 2016 about the Position, Organizational Structure, Duties and Functions, as well as the Working procedures of the Department of Education.

Local regulations Bogor Regency No. 4 of 2017 On the amendment of the Regulation of the Area of Bogor Regency Number 5 Year 2014 on the Medium-Term Development Plan of the Area. The formulation of the vision in such regulations is Bogor Regency became a Regency in Indonesia Advanced. To achieve this vision, the government of Bogor Regency set five Pancakarsa, and three of the five missions namely, Bogor Smart, Bogor Civilized, and Bogor Build. The Program is run the Department of Education as the strengthening of the educational service that is thorough, effective, and quality for the local community.
As a form of optimization and support program Regent Bogor Regency in applying Pancakarsa. The department of Education conducted a series of activities in the form of a program that includes five Pancakarasa. With the aim of improving the quality of service, as well as the competence of education for the local community. The program is made starting from the construction of the vital facilities in supporting teaching and learning activities in school. Not limited to the physical, the Department of Education also acceleration in the strengthening of the competence of Human Resources (HR) learners, educators and education.

Education Authorities Bogor Regency see standard policy success the quality of learning in PAUD Education can be seen from the increasing number of PAUD education that has been accredited, PAUD Kabupaten Bogor which amounts to less than three thousand five hundred of PAUD education has been accredited to about five hundred of PAUD education, the standard of the success of the policy PAUD education could also be seen from the increasing number of PAUD teachers who have followed the Training ranging from Basic level to advanced so that the competence of teachers is increasing in the method of learning so that more quality.

Standard policy success in the improvement PAUD education could also be seen from the increasing competence of teachers, especially teachers who are graduates of high school, so has the perception of similarity in the pattern and methods of teaching the same strata of education after being given education and training by the Department of Education of the Bogor Regency. The policy of the Department of Education of the Bogor Regency in the issue of the quality of learning is giving way teaching and learning method of the same according to the growth and development of the child, so that the learning was conventional to evolve with other methods such as the method of loospart, Steam and others. After a given 
Training the teacher can teach the learning material according to the region, such as when the geographical location of the institution of PAUD education it on the mountain then the learning material for example farming, gardening.

Still a lot of PAUD learning by means of conventional spt learn to read, write, calculate and finally slowly changed the mindset of conventional learning was to increase the capacity of the teacher, from year 2013 until 2017 dintervensi by UNICEF to all PAUD teachers to perform the repair of a learning system with the hope of being PAUD.

Real conditions show that PAUD Teachers in Bogor Regency, especially on the path of non-formal education has variations that vary in the qualification and competence. Still found a teacher who educated the basic (Elementary or Junior high school), however many educators who have the secondary education level (high school or vocational school) and a few educated diploma and bachelor's degree, though not relevant/appropriate to the field of PAUD education. Under these conditions, required Training and Education (training) of Teachers of PAUD education that aims to improve the competence of three levels of PAUD Teachers (PAUD teachers, teachers and teachers of the young) is continuous and tiered. The training includes the basic training, further training and training advanced. Basic training is intended to prepare educators with the minimum competencies as teachers of the young. Further training is intended to prepare Teachers with the minimum competencies as teachers and training proficient intended to prepare Teachers with the minimum competencies as a Teacher of PAUD education.

Training tiered is an effort to help teachers who have not yet matured into a ripe, which is not able to manage on their own to be able to manage on their own, and increase competence. Therefore, PAUD Teachers after the training Stages are expected to understand the issue of PAUD education and appropriate learning methods applied in PAUD education, including understanding nutrition, health, and stage of development of the child to the maximum.

PAUD education has a very important role in the development of human resources. The role of Educators and Education Personnel in dealing with the Institution of PAUD education are expected to have sufficient competence in their field. PAUD educators is most responsible for the implementation of the service of education quality in the community.

Therefore, it is necessary trainings and seminars in order to improve the quality of PAUD Educators. So the existence of the program and activities of the service PAUD Non Formal education in a comprehensive manner can be known, understood and explored by the competent authorities and to deal directly in the field (educators, educators and managers PAUD) is deemed necessary to hold a basic training for PAUD educators. The activities of the basic training are done to achieve the competency of educators as stated in decree No. 58 of 2009, which have competence in understanding the basis of PAUD education, skilled in carrying out the training, and have the attitude and behavior according to the needs of child psychology.

\section{The Implementation of The Policy PAUD Education}

According to Richard Gorton and Schneider (1991) "Implementing involves administrators in the process of making sure that the plant is carried out as intended." This means that implementation involves an administrator in the process of ensuring that the plan is proceeding as desired. Basically, the process of policy implementation is a process that is very decisive. A measure of the success of education policy can be viewed at the implementation stage. As well as any education policies that have been created if not implemented then it will not be able to benefit.

In the Socialization Policy PAUD education to improve the Quality of 

education.

Learning many parties involved and included such as: Assessor (which assess the quality standards of the institution), Himpaudi, IGTK, Overseer PNF/ trustees of the technical in the field, Bapeda, that eventually a lot of cost, time, energy issued in disseminating this policy, so that this policy can be justified legally. One of the only socialization policy implementations of accreditation to improve the quality of learning.

Plan of Action (PAUD education Program) according to the policy of the Department of Education of the Bogor Regency in improving the quality of learning is the improvement of the PAUD education program HI (Holistic Integrative). Holistic integrative is education that integrates all the aspects and values in education such as the value of the moral, ethical, religious, psychological, philosophical, and social in unity is done thoroughly between soul and body as well as aspects of material and spiritual aspect to meet the essential requirement of the child.

Integrative holistic not just studying the field of education, but also lessons related to health and nutrition, patterns of parental care and protection for children. Basically, the child is a totality of the whole, therefore, it needs a thorough education to fulfill the rights of children, one of them is to send him to PAUD holistic integrative.

To realize PAUD $\mathrm{HI}$ the regional level, the government of Bogor regency conduct a workshop on the preparation of the work programme of the cluster of activities is followed by a variety of crossUnit Working Card Area related to the management of PAUD. SKPD participate not only the Department of Education, but rather to the district level. This activity aims to form the structure of a list in the form of activity, up to the evaluation of the results of monitoring. This program will be along the entire institution of PAUD education in Bogor regency. By applying some standard, to maintain the quality of institutions and learners.
There are four basic program that will do a team of the cluster at the regional level. Education programs, child care, child protection, health and nutrition of children. The fourth basis of the program is monitoring task force teams. with this program, he hopes, thousands of PAUD institutions in Bogor regency has a good quality in the service process and education. The current number of PAUD has been approached three of the thousands of institutions. It indicates that the community needs for education of children is very high. Therefore, the government through this program, want to create PAUD.

Implementation of PAUD education HI basically flexible to adjust to local conditions and the ability of units of PAUD education is concerned. PAUD $\mathrm{HI}$ it is possible implemented in an integrated manner in Units of PAUD education, but allows also implemented separately in some places the service. For integrated services for example the child's medical examination is performed in Units of PAUD education by bringing the most health. For a separate service for example, when the examination of the health of the child PAUD is brought to the clinic according to the schedule service Ihc, activity counseling to Parenting is put together with the Development activities of the child. Second service patterns require cooperation between stake holders of Trustees.

The results of the research of Linda (2013) the Excess perceived parents of the implementation of the PAUD education program Integrative Holistic in PAUD education are: a). Established good communication between parents and school. b). Established communication and togetherness between the people of the old one with the parents of the other. c). Increase the knowledge. d). Add the skills of parents in nurturing and educating children. While the perceived disadvantages of the parents of the implementation of the program of PAUD education Integrative Holistic in PAUD education are : a). The learning material is limited. b). Learning 
conditions are less favorable. c). Meeting learning limited. d). The information is not conveyed to the parents who did not attend because of busy work or the other. e). Happened resistance or revolt by the child when parents apply the results of the learning.

\section{Barriers To The Implementation Of The Policy PAUD Education}

The growth of the institutions of early childhood education in Bogor regency is growing rapidly. But, it is very rare teachers who are graduates of the bachelor of early childhood education or psychology. Course competencies of PAUD teachers of the ideal is still very far from expectations. PAUD teachers are not in accordance with their competence will have a negative impact on the growth of the child early age, learning PAUD has different characteristics with the level of education to be achieved thereafter. In the law No. 16 of 2007 about the standard of academic qualification of the teacher explained that: academic Qualifications guru PAUD/TK/RA must have academic qualifications education minimum diploma empat (D-IV) or bachelor degree (S-1) in the field of PAUD education or psychology which is obtained from the accredited study program (Regulation of the Minister of National Education Republic of Indonesia Number 16 of 2007) PAUD Teachers implied titled S-1 PG-PAUD or D-4 PAUD education. In reality until now the teachers of PAUD education is still dominated by graduates of high school and only $38 \%$ are educated S-1, it was not an S-1 PAUD education.

Obstacles in the implementation of the policy PAUD education in Bogor regency is still constrained in HR, namely the number of institutions of PAUD education in the district of Bogor with the Viewer as the Builder of PAUD education is not balanced in number, of three thousand lambaga PAUD education in the district of Bogor there are only about 40 Inspectors who develop early childhood. But in spite of the institutional PNF PAUD Education
Department of Bogor, the number of human resources is limited they are still trying to maximize the development of PAUD education throughout Bogor by conducting training, workshops and skills of PAUD teachers to improve the quality of learning.

Implementation of PAUD education experienced a lot of obstacles are still limited mastery of science education educators, it is still limited funds to purchase educational games, and limited evaluation of the PAUD education program. Education in the PAUD caused by the educators have not mastered PAUD education. Mastery of PAUD educators of children is very low. A lot of educators that has been patterned with conventional learning because often view learning of basic education that develops first in the community. Education classroom with desks and chair for studying become one of the learning models that are commonly applied in group play. Whereas, indeed, the learning process can be done anywhere, including outdoors or nature. The process of learning as it inhibits the child to explore his / her own ability.

\section{The Results Of The Implementation Of The Policy PAUD Education}

Education Authorities Bogor

Regency PNF PAUD education have a responsibility to carry out training and coaching in improving the quality of learning PAUD education. So, in the implementation always refers to provisions that have been set. Thus, gradually the programs and activities of the service PAUD Non Formal education in particular has increased-increased, both in quality and quantity. Therefore, the required training and seminars in order to improve the quality of PAUD Educators. So, the existence of the program and activities of the service PAUD Non Formal education in a comprehensive manner can be known, understood and explored by the competent authorities and to deal directly in the field (educators, educators and managers of PAUD education). 
In addition, it is deemed necessary to hold a basic training for PAUD educators. The activities of the basic training are done to achieve the competency of educators as stated in decree No. 58 of 2009, which have competence in understanding the basis of PAUD education, skilled in carrying out the training, and have the attitude and behavior according to the needs of child psychology.

As a district near the capital, the Government of Bogor Regency has a vision to become the district the most advanced Indonesia. In order to achieve this vision, the mission carried out, among others, improve the accessibility and quality of education the Steps taken by the Government of Bogor Regency in realizing the mission of improving the accessibility and quality of education and health services is to provide educational services that are equitable and affordable, as well as enhance the professionalism and accountability of the administration and management of education.

In providing education services, equitable and affordable, the Government of Bogor Regency strives to provide service PAUD education affordable. The goal is increasing the expansion of access and equity of PAUD education quality. In addition, it also seeks to provide certainty to obtain service elementary education or secondary education that is equitable and quality. Similarly with the availability of the services of non-formal education, equality, and functional literacy for citizens who are not netted formal education.

Another mission undertaken by the Government of Bogor Regency is to improve the capacity and professionalism of human resources education. The goal is the fulfillment of the number, qualifications, and competence of teachers in accordance SPM in order to meet the national standards of education at all levels. In addition to improving institutional capacity and accountability of the implementation of the functions of administration and management of educational organizations, so as to materialize institutional governance effective and accountable in order to optimize the function of public service the department of education.

Teachers that are not in accordance with the qualification/competence would result in impact on the development of PAUD education. Learning in PAUD education have different characteristics with the level of education thereafter. If the teacher does not have the competence in the field of PAUD education will possibly happen misperceptions in the implementation of learning and the impact it is precisely on the development of the child.

When viewed from the profile of the teachers that most high school graduates course, the competence of the teacher of PAUD education of the ideal is still far from expectations. It has certainly been a challenge for local government to continue to improve and improve the quality of Education and Low level of education of PAUD teachers resulted in similarly low quality orphanage against early childhood, because it is still low quality teacher/ PAUD educators who do not meet the minimum standard that is to be PAUD educators must became certified at least equivalent to the program D-4 PGTK (Teacher Education Kindergarten)

The reality in the field of education for PAUD is currently only held develop for cognitive ability and keep the child from the situation of the culture that surrounds it. Almost all of the institutions of PAUD education make learning to write, read and count as a core activity. Parents and teachers seemed to impose the expectations of the child to the child to be smart in the academic and forget about the nature of the child to grow and develop naturally. Efforts in improving the quality of education through human resources, one of which is a factor of educators or teachers who have a major role in improving the quality of education itself. This is because teachers act as agents of learning and face to face and interact with students. Therefore need to be held coaching in the form of training, seminar, or workshop with the aim of 
improving the quality of teachers to better understand how to optimize the students in the school.

In this field Bogor Regency Government through the Department of Education of the District of Bogor in particular the Field of PAUD Development and the PNF, implement the program in the form of logging and tracing of PAUD institutions in the scope of the area of Bogor Regency to determine the extent of the presence and quality of the institutions of PAUD Education as well as coaching and education by applying some standard methods to keep the quality of the institution and the students. As for the program includes Education, parenting child, child protection and health and nutrition of children contained in the PAUD Holistic Integrative.

Therefore Bogor Regency Government through the Department of Education of the Bogor Regency with this program strives to create PAUD in line with the Program of the Regent of Bogor in PANCAKARSA, namely : Karsa Bogor Intelligent, and through this program, make Bogor Regency more advanced include the means and operational.

\section{CONCLUSIONS}

Based on the results of research that has been done regarding the policy of the Department of Education of the Bogor Regency in improving the quality of PAUD education it can be concluded as the following:

1. Policy PAUD Education in improving the quality of learning in the Department of Education of the Bogor Regency has been implemented with a maximum in the competence of the teacher by providing education and training as well as provide assistance incentives on teachers.

2. The implementation of the Policy PAUD Education Department of Bogor Regency, especially in the Field of PAUD education PNF always synergism and partnered with the organization / institution / association of a similar group, whose members are managers, educators, namely: ( Himpaudi, IGTK ), through the officers of the Overseer in disseminating all the PAUD education program in the district of Bogor.

3. Obstacles in implementing the Policy of PAUD education in Bogor Regency is still constrained in HR, namely the number of institutions of PAUD education in the District of Bogor with the Viewer as the Builder of PAUD education is not balanced in number, of three thousand lambaga PAUD education in the District of Bogor there are only about 40 Inspectors who develop early childhood. But in spite of the institutional PNF PAUD Education Department of Bogor, the number of human resources are limited they are still trying to maximize the development of PAUD education throughout Bogor to conduct training-training, workshops and skills of PAUD teachers to improve the quality of learning.

4. The results of the Implementation of the Policy PAUD education in improving the Quality of Learning. In terms of the implementation of PAUD education quality as a Government program with the program PAUD Holistic Integration (PAUD HI) provide attraction and satisfaction to the parents of the students, with the involvement of all parties in addition to the Department of Education also bunda-bunda PAUD which acts as a policy giving special attention to education at this age. The regent of Bogor Regency at once as the mother of PAUD Bogor Regency do the Movement "Let's go to PAUD Education" to ensure no more children an early age that directly enter primary School without going through the level of PAUD education.

\section{Acknowledgement: None}

Conflict of Interest: None 


\section{Source of Funding: None}

\section{REFERENCES}

1. Arikunto, Suharsimi (2002). Metodologi Penelitian. Jakarta : Rineka Cipta.

2. Arwildayanto, et al. (2018). Analisis Kebijakan Pendidikan Kajian Teoritis, Eksploratif, dan Aplikatif. Bandung: Cendekia Press.

3. Deming E. (1982). Quality, Productivity, and Competitive position. Third Edition, McGraw Hill. United States.

4. Dunn, William N. (2000). Pengantar Analisis Kebijakan Publik. Penerjamah Samodra Wibawa, Diah, Agus, Erwan. Jogjakarta: Gajah Mada University Press.

5. Dunn, William N. (2003). Pengantar Analisis Kebijakan Publik. Penerjamah Samodra Wibawa, Diah, Agus, Erwan.Jogjakarta: Gajah Mada University Press.

6. Fattah Nanang. (2012). Analisis Kebijakan Pendidikan. Bandung : PT Remaja Rosdakarya.

7. Hadis, Abdul dan Nurhayati (2010). Manajemen Mutu Pendidikan. Bandung: Alfabeta.

8. Haenilah, Een Y. (2015). Kurikulum dan Pembelajaran PAUD. Yogyakarta: Media Akademi.

9. Hasbullah. (2015). Kebijakan Pendidikan Dalam Perspektif Teori, Aplikasi, dan Kondisi Objektif Pendidikan di Indonesia. Jakarta: Rajawali Pers.

10. Islamy. (2002). Prinsip-prinsip Perumusan Kebijakan Negara. Jakarta : Bumi Aksara.

11. Jamaris Martini. (2006). Perkembangan dan Pengembangan Anak Usia Taman Kanak-kanak. Jakarta: Grasindo. Hlm. 104-105.

12. Latif, Mukhtar et al. (2014). Orientasi Pendidikan Anak Usia Dini, Teori dan Aplikasi. Jakarta: Kencana.

13. Moleong, J Lexy. (2009). Metode Penelitian Kualitatif. Bandung : PT. Remaja Rosdakaya.
14. Nugroho Riant, et al. (2008), Pengantar untuk memahami Kebijakan Pendidikan dan Kebijakan Pendidikan sebagai Kebijakan Publik. Yogyakarta : Pustaka Pelajar

15. Parsons, Wayne. (2005). Public Policy. Pengantar Teori dan Praktik Analisis Kebijakan. Jakarta : Kencana.

16. Purwakania, Aliah B (2006). Psikologi Perkembangan Islami. Jakarta : PT Raja Grafindo Persada.

17. Richard A Gorton and Gail Thierbach Scheineder. (1991). School Based Leadership: Challenges and Opportunities. New York: Wm.C. Brown Publisher.

18. Rozi Sastra Purna et al. (2015). Psikologi Pendidikan Anak Usia Dini. Jakarta : PT Indeks.

19. Sagala, Syaiful. (2007). Manajemen Strategik Dalam Peningkatan Mutu Pendidikan. Bandung: Penerbit Alfabeta.

20. Sallis, Edward (2015). Total Quality Management In Education. IRCISOD, Yogyakarta.

21. Istiqomah Laelatul (2016) Tiga Pilar Kebijakan Pemerintah Dalam Pembinaan Paud. Golden Age Jurnal Ilmiah Tumbuh Kembang Anak Usia Dini. Vol. 1 No. 1 April 2016 : 57-65.

22. Jalal, Fasli. (2002). Meningkatkan Kesadaran Masyarakat Akan Pentingnya PADU. Buletin Padu Jurnal Ilmiah Anak Dini Usia. 03. 9 - 18.

23. Linawati Zulfa. (2013). Penyelenggaraan Program PAUD Holistik Integratif di PAUD Siwi Kencana Kota Semarang. Journal Of Non Fomal Education And Community Empowerment.

24. Sarinasitin. (2019). Pendidik Holistik Integratif untuk pembentukan karakter Anak Usia Dini. Jurnal Lonto Leok Pendidikan Anak Usia Dini, Volume 2, No 1, Januari

25. Peraturan Pemerintah, 2003, UndangUndang Republik Indonesia Nomor 20 Tahun 2003 tentang Sistem Pendidikan Nasional. 
26. Peraturan Pemerintah, 2005, Peraturan Pemerintah Republik Indonesia Nomor 19 Tahun 2005 tentang Standar Nasional Pendidikan

27. Peraturan Presiden Nomor 60 Tahun 2013, tentang Pengembangan Anak Usia Dini Holistik Integratif.

28. Peraturan Daerah Kabupaten Bogor, Tahun 2011, tentang Penyelenggaraan Pendidikan.

29. Perbup Kabupaten Bogor Nomor 45 Tahun 2016 tentang Kedudukan,
Susunan Orgaisasi, Tugas dan Fungsi serta Tata Kerja Dinas Pendidikan.

How to cite this article: Srihartini Y, Wasliman I, Iriantara Y et.al. The policy of the department of education Bogor regency in improving the quality of PAUD education. International Journal of Research and Review. 2021; 8(11): 272281. DOI: https://doi.org/10.52403/ijrr. 20211135 